\title{
City Space in the Postcolonial City in Javanese Novel "Sapecak Bumi sing Kobong" by Hastin Zaina
}

\author{
Yunita Ernawati \\ Universitas Negeri Surabaya \\ Surabaya, Indonesia \\ yunitaernawati@unesa.ac.id
}

\author{
Sri Wahyu Widayati \\ Universitas Negeri Surabaya \\ Surabaya, Indonesia \\ sriwahyu@unesa.ac.id
}

\author{
Sri Sulistiani \\ Universitas Negeri Surabaya \\ Surabaya, Indonesia \\ srisulistiani@unesa.ac.id
}

\author{
Bambang Purnomo \\ Universitas Negeri Surabaya \\ Surabaya, Indonesia \\ bambangpurnomo@unesa.ac.id
}

\author{
Mohammad Rokib \\ Universitas Negeri Surabaya \\ Surabaya, Indonesia \\ mohammadrokib@unesa.ac.id
}

\author{
Hespi Septiana \\ Universitas Negeri Surabaya \\ Surabaya, Indonesia \\ hespiseptiana@unesa.ac.id
}

\begin{abstract}
The war period has an impact on the city that is considered as a safe area to be a conflict-prone area. Colonial control made the existence of the city as a matter of debate. Sapecak Bumi sing Kobong, a novel by Hastin Zaina is a modern Javanese novel which presents dominations of colonial control. Through the spatial politics framework, this article discusses how the city space in the novel is constructed. The economic, social and political dominance are the formal object analysis. This paper argues that the urban space that was originally considered as a utopia began to shift into dystopia. The fact of colonial control left the indigenous people treated differently so they had to work harder. The identity possessed by the indigenous peoples in shaping the city had been ignored in the colonial urban space, as indigenous peoples became subject of the decline. Therefore, it is seen that Hastin Zaina constructs city space into a space that rejects utopia.
\end{abstract}

Keywords—postcolonial; city space; Javanese novel

\section{INTRODUCTION}

The impact of war can be felt by every nation. The colonized people were affected most with the war. At first they lived in a peaceful area, but with the war the peace was disturbed. Some of them can escape from the area in hopes of getting a decent life change. Representation of the colonizer namely the natives are found in the novel by Hastin Zaina [1] entitled Sapecak Bumi sing Kobong. In the novel, Zaina [1] tells how the indigenous life against the invaders with the background of one city in East Java. Most of current discussion within literary studies in Indonesia is dominated by Indonesian-written literary works [2] [3] [4], Thus in the novel Sapecak Bumi sing Kobong is clearly seen postcolonial's point of view owned by the author. Why this novel is interesting to be discussed within the frame of postcolonial's perspective? Here, this paper argues that studying Javanese novel enriched with the value of city space through postcolonial perspective is merely conducting by previous researchers. Most of them focus on the structural aspect, especially in terms of social and cultural values. Thus, looking at the city space aspect can fill the gap within the field of research. In addition, city space studies are dominantly conducted within the study of urbanism planning or government studies. Therefore, the case of novel as an imagination of city space can fill the gap in the studies. This novel has the background of a city in East Java. This research will discuss about the postcolonial city space that is represented in the Javanese novel.

\section{METHOD}

\section{A. Design}

This study uses city space theory of Sara Upstone [5] with the title Spatial Politics in Postcolonial Novel. Upstone [5] offers a postcolonial's view through colonial experience. According to Upstone [5], "....a reading of the postcolonial politics novel that is centered upon an alternative concept of spatial politics: one that is rooted not a solely in a politics of the nation, but instead reflects the disability spaces that construct the postcolonial experience". Colonial experience occurred in areas or communities that experienced colonial rule or control. As cited by Endang [6], Upstone [5] offers the reading of these postcolonial experiences constructed in several spaces, among them the state space, travel space, city space, home space and body space. 


\section{B. Data}

This research uses Sapecak Bumi Sing Kobong novel by Hastin Zaina [1] as data. Novel Sapecak Bumi Sing Kobong which will be written SBSK consists of 156 pages. This novel SBSK was published by PD Nusa Jaya in 2010.

\section{Data Collection}

According to Faruk [7], method of data collection means a set of ways or techniques to get empirical facts related to the problem of literary research. The data collection in this research is done in the form of primary data collection and secondary data. Primary data is from the texts on SBSK novels. While secondary data comes from a number of references i.e. books, journals or other studies that have to do with the object of study. Data collection by way of literature study that researchers collect data related to research problems.

\section{Data Analysis}

Method of data analysis is a set of ways or techniques to attract relationship between one data and the other data that leads to a scientific knowledge [7] [8]. The analysis in this study uses descriptive qualitative analysis.

\section{RESULTS AND DISCUSSION}

The city space theory from Upstone [5] in his book Spatial Politics in Postcolonial Novel will be used in this study. Upstone [5] offers a postcolonial's view of space as a controlling strategy of the colonial authorities. According to Upstone [5], where marks of colonial control refers to the space which is broader and more flexible is a form that colonialism wishes to obscure. Based on the explanation of Upstone [5], there is a difference between place and space. Space is more flexible or softer, it is advantageous to the colonial. The flexible nature of space allows the colonials to easily incorporate their concepts and ideas. Such concepts and thoughts can ultimately obscure the forms of space.

The blurring forms of space is a strategy for colonial's rulers to dominate a colony. Therefore, the colonial caried out the strategy the ruler to control the community and its territory. In this novel, SBSK is clearly visible to control the Dutch as the colonial ruler of the indigenous Javanese society, as in the following quotation;

\section{"Republikein?"}

Ganti Moko sing mandhengi kondektur kanthi mencereng, nuli kepeksa blaka. Dheweke manthuk semaur, "Leres".

Kondektur mau manthuk-manthuk banjur kandhane lirih. "Adhik mriki kemawon. Stasiun sampun dikuwasani Landi....."

\section{["Republican?"}

Changed Moko who watched the conductor by glaring, thus being forced to be honest. He nodded his head and replied, "Right."

The conductor nodded his head while he said slowly. "The younger brother goes down here. The station has been Dutch control...."]

Based on the excerpt above, it is visible that Dutch control the native originated from the planting of thought between the boundaries between two. These constraints are seen as a strategy in perpetuating the Dutch's goal to colonize indigenous territories, for example Republikein, the word refers to the militant natives defending their city from the Dutch colony. Indigenous ultimately know the limits made naturally by the Dutch. Therefore, the invanders create an identity for the indigenous and land called Republikein. Colonial's control is not only limited to the identity of the natives but also to the certain areas of the city.

The concept of boundaries is present in the urban space as a form of preventing the presence of resistance. The absolute boundary concept made Dutch control of the city an indispensable thing to the natives for being made as natural. The natural control strategy is seen as a construction that was initially not realized by the natives. According to Adzani [9], imperealism reinforces its power over territorial which is then mapped as its territory, and instills its superiority in its power. It is also visible in the SBSK, the Dutch have been planned the city's space for their power. The large station located in the city's room has become the territory of the Netherlands. The station is one of the places considered to be prone to chaos for the Dutch. It is a place to enter and exit the city, then the Dutch control is very dominating.

\section{A. City Space}

The possibility of resistance and the existence of identity negotiation can be seen through the analysis of urban space construction through the postcolonial theory of Upstone [5]. The chaos of resistance is not only in nation but also in small scale that is city. City is a space that is a reflection of national tensions and has its own geopolitics [5]. Based on the excerpt above, Upstone [5] offers a definition of the city as one of the space that represents postcolonial's movements. Tension begins in the space of the nation then it affects the space of the city. It is matched by the offer of a distinctive geopolitical idea. This small-scale space plays an important role in Dutch colonial control.

The controls made it easy for the Netherlands to carry out its political functioning of the city space. The control is also related to the concept of bounded territory. This concept is used to protect the territories that colonialists have claimed as their territory. The flexible city's space allows the Dutch to easily provide hegemonic concepts. The concept given to the city's liquid space allows for resistance from the natives. Therefore, through his reading of the postcolonial, Upstone [5] saw the existence of an association between the authors and the city. How the authors represent the cities with all the hegemonic concepts that colonial and dreamy cities provide. There are two possible authors in representing the city. First, the depiction of a dream city is the same as reality. Second, the portrayal of the dream city is not the same as the reality so it raises ambiguity.

According to Upstone [5], the author has a role in providing ideas for the construction of city space is considered perfect. Author has a share in the ideal city portion poured Upstone [5] in the following quotation. "This connection between colonial cities and the utopian ideal city presents opportunities to explore how postcolonial novelist engage the urban space of colonial nation and postcolonial is replicated on urban scale" [5]. In line with the opinion of Upstone [5], Zaina as author of this novel SBSK also describes the city. The depiction of the city in this 
novel has many postcolonial concepts in accordance with the style shown by Upstone [5]. In this novel, there is an ideal city depiction through the mention of details of vital places in the city such as stations, markets, roads, and homes. These places have a certain context which later by the Dutch was constructed as a colonial area. In addition, the places that exist within the city is a vital object that is bound as a symbol of Dutch power as one of the control of the city.

\section{B. Space Structure in the City}

The city in SBSK novel is a city in East Java. The depiction of the city structure begins with stations, homes, markets, shops and factories. The city becomes an important place for residents who live in or around it. It is because the city became the center of the economy that is able to support the surrounding population. Many residents makes money by becoming workers and traders in the city. In the following quotation mentioned the structure of the city;

\section{"Toko-toko lan omah gedhe-gedhe sing biyen isih wutuh..."}

["Shops and big houses that were still intact ..."]

Based on the excerpt above, the author describes a city with a store structure and a large house. Thus, the author tries to make a difference between the city and the village through the mention of big houses. The big house is identified with the elite house or in other words only the wealthy upper middle class who can afford big house. The mention of this big house seems to be attached to the person who owns and inhabit it. The large houses in the center of the city are indicated by the priyayi who have them. The mention of priyayi here is not exaggerated because in the Javanese society it is familiar with the classification of social class. According to Sarjana and Kuswa [10] the Javanese society is divided into 4, namely: the common people and the crude workers (wong cilik), the traders (saudagar), the government (priyayi), and Javanese aristocracy (bendara). Referring to these four groups, the Javanese society thicken the classification based on social status in running their lives. The priyayi and nobles occupy the highest caste positions in Javanese society. Azina [1] shows the caste through the two main characters namely Nuraini and Harmoko. Nuraini lives in the city and inhabits a big house. Nuraini's parents are one of the honorable people in the city. His sister named Sudrajat was appointed as a Dutch's soldier while his mother as head of the steward at the Dutch headquarters. While, Harmoko is an orphan who lives a simple life.

The description of the big house with its inhabitants further strengthens the colonial concept that is beginning to be present in the domestic realm. The rigid colonial concept cannot rule out the possibility of chaos as a result of the resistance effort of some home occupants. According to Upstone [5] (in Suciati [6]), postcolonial also want to reveal chaos in the home to happen because 'not all inhabitants of the house support the colonial ideal'. Zaina [1] eloquently describes the chaos in the domestic realm of a large house. Through the father figure of the figure Nuraini, Zaina [1] began to show the existence of resistance to the concept of a rigid colonial.

“Aku iki ora seneng roti bu, amis," keprungu swarane bapake nggremeng, banjur, "Wingenane aku rak wis kanda, aku ora setuju nek Drajat mlebu dadi serdhadhu... dene saiki oleh jatah roti, jatah keju, susu ya kukupen dhewe!
["I do not like bread, mom, it smells fishy," the voice of his father grumbled, then, "yesterday I told you, I did not agree that Drajat was a soldier... now get bread, cheese, milk, you eat by yourself!'”]

Based on the excerpt above, it is seen that the colonial concept still began to affect the patriarchal tradition by the Javanese community. This tradition makes the father or father as head of the household to be obeyed, began to fade with the entry of the colonial concept. Therefore, the opposition to the colonial brings a chaos with other family members namely his wife and his eldest son. Fixed and strong colonial concepts produce hegemony capable of fading the tradition that has been run.

In addition to large houses and shops, Zaina [1] also mentioned the factories and warehouses on SBSK novels. Then, this city space becomes one of the vital objects that are very influential with the speed of the economy. Zaina [1] describes the city as a place of industry, along with this excerpt;

"Bangunan-bangunan pabrik dalah gudhang-gudhang

\section{["...Factory buildings and warehouses are destroyed ..."]}

The excerpt above shows that the colonial control to gain indigenous territory through the strategy of destroying some economic centers such as factories, markets and warehouses. In this city hall, Zaina [1] describes the sugar factory that became the economic center of the local people. This sugar factory is very strategic where is between the market and the warehouses. Then, most people in the city or from out of town depend their lives through the existence of sugar production in the factory. The existence of these three places makes the city as a very strategic public sphere to embed the colonial concept. The urban space of a liquid nature requires control for the sake of preserving the colonial concept. Thus, the Dutch chose to destroy some sugar factories as an effort to control the urban space is liquid. The destruction of the sugar factory that has been used as a place of work in the majority of urban society then it can reduce the possibility of resistance and chaos.

However, Azina [1] points out that the destruction of the plant does not necessarily eliminate resistance. Some people who are aware of these controls attempt to show resistance through various means. One of them by writing inscription on the walls of the factory collapsed. As in the following excerpt;

"slogan-slogan MERDEKA ATAU MATI, LEBIH BAIK MATI DARIPADA DIJAJAH KEMBALI, SEKALI MERDEKA TETAP MERDEKA, tinulis sumebar ing ngendi-endi..."

["slogans of DEFENDING OR DEAD, BETTER OFF FROM THE DIVISION BACK, ONCE THEY REMAINED, written everywhere ..."]

Through these slogans, indigenous people showed their resistance to Dutch's power. Because of the existence of the slogan, the Dutch then spread their troops to patrol in the city. Thus, the boundaries of the natives were created by the Dutch through their soldiers. The boundaries created by the Dutch are a control for urban space control. 


\section{Space Structure Outer of City}

The boundaries established by the Dutch in the urban space caused resistance and chaos. The effort of resistance are illustrated through space outside the city. Rigid urban spaces make some urban dwellers choose to go out of town. Space outside the city is considered more fluid and safer. Mountains outside the city, selected by Zaina [1] as a place of citizens who call themselves guerrillas to stay for their safety.

"Dheweke nedya munggah gunung, lan saiki dheweke wis weruh sepira gedhene tresnane Harmoko marang dheweke. Dilabuhi nekad mlebu kutha sing kebak bebaya..."

["He intends to go up the mountain and now he already knows how much Harmoko love towards her. It is defended by desperation to enter a dangerous city... "]

For urban society, the urban space used to be liquid becomes rigid and dangerous as the colonial control goes on. Thus, the guerrillas shifted out of town which is considered more fluid and remains liquid that is mountainous area. This steep and difficultto-reach track give the benefits for the guerrillas in crafting a strategy of resistance to colonial.

In another sense the mountain is a place far from the city space. In this novel, Mount is identified with the most outermost urban space as it is still considered a potential area for the Dutch. Therefore, the existence of this mountain can replace the utopian city that had been dreamed by the people of the city. For this reason, the guerrillas began to come and occupy this mountainous region. They consider that new space besides city space can provide the sense of security they need. Here is an excerpt that shows that the mountains can reassure their hearts.

"Hawane seger, hawa pagunungan sing nentremake ati”.

["It's fresh, mountain air is reassuring."]

This mountain region provides space for guerrillas in this case Harmoko and his friends to do the resistance. In this new space, the guerrillas abandon all the social status they get in the city. Both as wong cilik and priyayi cooperate in that space. They are ready to accept the fact that they have to work harder to gain their freedom inside and outside the city space. Then, in the end the mountains cannot realize their utopian hope because the reality demands them to dare to sacrifice their lives for the sake of national independence.

Another place mentioned in this novel is the river SBSK in the middle of the forest. The existence of the river in the middle of this forest gives a new nuance that cannot be found in the city space. The river became the choice of places visited by the guerrillas to gain peace. A sense of peace he had not felt in the city hall since the Dutch presence. Azina [1] managed to describe the scenery and river atmosphere in the middle of a very beautiful forest. As in the excerpt below;

"Alam ing sakubengen mujudake kalangan sing resep kanggo padusan ing tengah alas sing nentremake ati".

["The surrounding nature creates a very nice place to bathe in the middle of a forest that reassures the heart".]

River in the middle of this forest becomes a place to bathe for the guerrillas. It's right under the guerrilla headquarters. Cool atmosphere with beautiful scenery can reassure you. Not possible with the existence of this river can lead to ideas of utopia when the guerrillas bathe. For a moment, these ideas merged with the desire for independence possessed by the guerrillas, but it cannot remove the existing reality. Therefore, the guerrillas did not take long to wake up and remember the struggle they were doing for the country. Like the following excerpt;

“...ura-ura ing perengan krasa saya nentremake atine. Dheweke banjur kelingan bumi sing ditinggalake...”

["...singing on the edges feels reassuring. He then remembered the earth left behind... "]

Liquid space like this river still cannot realize the utopia they dreamed of. Then, the guerrillas decided to keep fighting for the sake of a peaceful city space like before the Dutch came. Although the guerrillas are aware that the business is high-risk, it does not shake their desires for independence.

\section{CONCLUSION}

This SBSK novel shows the existence of colonial concepts given by the Dutch to the colonized society. The concept is easily portrayed into the realm of urban space. This is due to the urban nature of the liquid and heterogeneous society, making it easier for the Dutch to provide their colonial councils. Through colonial strategy, the Dutch began to give control over the natives in order to hegemony the native's territory. Strategy begins by giving a natural boundary and flowing into the urban space. The Dutch changed the market that was originally a center of trade and the center of urban community activity became the headquarters of the Netherlands. It aims to control the movement of indigenous peoples to suppress the number of people who will do the possibility of resistance. The Netherlands provides control over the station area, with the aim of controlling the entrance of indigenous communities. Factories and warehouses also became places that received control from the Netherlands. Then, it appears that Dutch control not only on the territory in the city space, but also in terms of the economy. The Dutch control also had an impact on large houses and their inhabitants.

The control of the Dutch cannot withstand the onset of chaos in the city hall. The emergence of chaos in the city hall was accompanied by the awareness of the natives to carry out resistance. The colonial control also have hit the tradition that had been in live by the indigenous communities of Javanese society. In the end, the guerrillas chose to get out of the city room into the outer space of the city, which is the mountains. Their identity and social status were abandoned when they were already on the mountain, which became known as the guerrilla bases. This is because the mountains are huge space compared to the city space that has been supervised by the Dutch. At first, guerrillas are in the mountains done as an effort to find the peace they once felt in the city space. However, the beauty of the city's tranquility is only briefly due to the existence of awareness to reclaim independence in order to realize the utopian city that they had dreamed of.

\section{REFERENCES}

[1] H. Zaina, Sapecak Bumi Sing Kobong, Surabaya: Nusa Jaya, 2010. 
[2] M. Rokib, "Reading popular Islamic literature: Continuity and change in Indonesian literature," Heritage Nusantara, vol. 4, no. 2, p. 183, 2015.

[3] D. N. Djenar, "On the development of a colloquial writing style: Examining the language of Indonesian teen literature," Bijdragen tot de taal-, land- en volkenkunde, vol. 164, no. 2, pp. 238-268, 2008.

[4] A. Syahreza, "The topicality of pre-colonial Indonesian heroes: Recent popular fiction from Indonesia," Bijdragen tot de taal-, land- en volkenkunde, vol. 168, no.1, p. 118, 2012

[5] S. Upstone, Spatial Politic in the Postcolonial Novel, Farnham Surrey: Ashgate Publishing Company, 2009.

[6] S. Endang, "Ruang pascakolonial dalam: The God of small things Karya Arundhati Roy,” FIB UGM, Yogyakarya, 2014
[7] Faruk, Metode Penelitian Sastra: Sebuah penjelajahan awal, Pustaka Pelajar: Yogyakarta, 2012

[8] Faruk, Belenggu paca-kolonial: Hegemoni dan resistensi dalam sastra Indonesia, Yogyakarta: Pustaka Pelajar Offset, 2007.

[9] S. A. Adzhani, "Konstruksi kota dan respon spasial dalam novel poskolonial: The kite runner karya Khaled Hosseini," FIB Universitas Gadjah Mada, Yogyakarta, 2014

[10] H. Sarjana, dan E. Kuswa, "Pranata sosial dalam masyarakat Jawa", Yogyakarta: CV Grafika Indah, 2009 